\title{
FUNCTIONAL RELATIONSHIP BETWEEN GRAIN YIELD AND SPIKES PER SQUARE METER OF WHEAT AS INFLUENCED BY SEED RATE UNDER LATE SOWN CONDITION
}

\author{
M.A.K. Mian*, A.A. Begum and R.R. Saha \\ Agronomy Division, BARI, Gazipur 1701 \\ Corresponding E-mail: mianmd.abulkhayer@yahoo.com \\ (Received: 29 August 2019, Accepted: 16 October 2019)
}

Keywords: Functional model, grain yield, spikes $/ \mathrm{m}^{2}$, wheat, late sown

\begin{abstract}
An experiment was conducted at Agronomy Research Field of Bangladesh Agricultural Research Institute, Gazipur for five consecutive years (20142015 to 2018-2019) to establish a functional relationship between grain yield and spikes $/ \mathrm{m}^{2}$ of wheat at late sown condition. Variation of spikes $/ \mathrm{m}^{2}$ was created by five seed rates $(90,120,150,180$ and 210 $\mathrm{kg} / \mathrm{ha}$ ). Pooled average value of spikes $/ \mathrm{m}^{2}$ was observed the highest (479-506) in $180-210 \mathrm{~kg}$ seed /ha. From the structural treatment, the highest grain yield (pooled average of $3876-4153 \mathrm{~kg} / \mathrm{ha}$ ranged 3295$5028 \mathrm{~kg} / \mathrm{ha}$ ) of wheat was produced in the seed rate of $150-180 \mathrm{~kg} / \mathrm{ha}$. The estimated optimum seed rate was found $162.29 \mathrm{~kg} / \mathrm{ha}$ with the estimated grain yield $3989 \mathrm{~kg} / \mathrm{ha}$ of wheat at late sown condition through the developed function model of $\mathrm{Y}=485.91+43.17 \mathrm{X}-0.133 \mathrm{X}^{2}$ $\left(\mathrm{R}^{2}=0.87\right)$. Again, the estimate optimum spikes $/ \mathrm{m}^{2}$ was noticed 423 when the estimated grain yield of wheat was $4135 \mathrm{~kg} / \mathrm{ha}$ at late sown condition through the developed functional model of $\mathrm{Y}=-2837+32.98 \mathrm{X}$ $0.039 \mathrm{X}^{2}\left(\mathrm{R}^{2}=0.83\right)$. The grain yield would be increased about $13 \%$ as compared to recommended seed rate $(120 \mathrm{~kg} / \mathrm{ha})$ of wheat. Spikes / $\mathrm{m}^{2}$ had significant positive correlation with seed rate $(r=0.79$ at $p=0.05)$ of wheat. Relationship between observed grain yield and predicted grain yield (when relationship between spikes $/ \mathrm{m}^{2}$ and grain yield) showed a good consistency $\left(\mathrm{Y}=1.0006 \mathrm{X}, \mathrm{R}^{2}=0.94\right.$ and $\mathrm{r}=0.97$ at $\left.\mathrm{p}<0.01\right)$. From the results of the study it is concluded that $162 \mathrm{~kg} / \mathrm{ha}$ of seed rate and 423 spikes $/ \mathrm{m}^{2}$ would be optimum for maximum yield) $4135 \mathrm{~kg} / \mathrm{ha}$ ) of wheat at late sown condition.
\end{abstract}

\section{Introduction}

Wheat is an important cereal food grain after rice in Bangladesh. Wheat cultivation increased (4.29 times) after independence of Bangladesh (1971) due to development of high yielding varieties along with improved production technology (BARI, 2011; BARI, 2017; AIS, 2018). In Bangladesh, area coverage of wheat is 428800 hectares with an annual production of 1423600 tons (AIS, 2018). Optimum sowing time of wheat is 15 November to 30 November in Bangladesh (BARI, 2017). The majority farmers usually grow wheat in the same land after harvesting of $\mathrm{T}$. aman rice and thus, sowing of wheat is often delayed (BARC, 2013). Sowing of wheat in Bangladesh may extend upto 20 December depending on the weather, topography and harvesting of the preceding rice crop (BARC, 2013). Grain yield of wheat is reduced @ $82-87 \mathrm{~kg} / \mathrm{ha} /$ day $(32-36 \%)$ after 30 November sowing (Begum and Mian, 2019). Spikes $/ \mathrm{m}^{2}$ is a major yield component which has a significant effect on the grain yield of wheat (Kadumet al., 2019). The increase of spikes $/ \mathrm{m}^{2}$ increased the grain yield of 
Mian et al.

wheat (Mian, 2008; Shankarraoet al., 2010). Spikes $/ \mathrm{m}^{2}$ is mainly influenced by seed rate and yield is the function of spikes $/ \mathrm{m}^{2}$ of wheat (Bolton, 2018; Sokoto et al., 2012). More number of tillers as well as more number of spikes $/ \mathrm{m}^{2}$ is generally noticed in higher seed rate (BARI, 2018; Nimat et al., 2013). Proper growth environment also enhances tillering as well as spikes $/ \mathrm{m}^{2}$ of wheat (Mian, 2008; Njuguna et al., 2010). Again, the excess seed rate would create more competition among the tillers producing lower effective spikes $/ \mathrm{m}^{2}$ and grain yield of wheat (Seleiman et al., 2016). On the other hand, lower seed rate produces higher number of tillers per plant up to a level if proper growth environment is provided. Delayed sowing due to late harvesting of $\mathrm{T}$. amanrice and excess soil moisture in southern part of the country reduce grain yield of wheat (BARC, 2013). At late sown condition, crop growth is retarded with reduced tillering of wheat producing lower grain yield. Moreover, only main tiller (stem) produces effective spikes but lateral or tender tiller fail to produce effective tiller or spike at late sown condition. In modeling concept scientists are trying to establish relationship between yield and spikes $/ \mathrm{m}^{2}$ of wheat for estimating the optimum spikes $/ \mathrm{m}^{2}$ for maximum yield (Mian et al., 2012; Moucheshi et al., 2013; Bolton, 2018). Therefore, the experiment was undertaken to establish a functional relationship between grain yield and spikes $/ \mathrm{m}^{2}$ of wheat and to estimate the optimum spikes $/ \mathrm{m}^{2}$ for maximum grain yield at late sown condition.

\section{Materials and Methods}

An experiment was conducted at Agronomy Research Field of Bangladesh Agricultural Research Institute, Gazipur to establish a functional relationship between grain yield and spikes / $\mathrm{m}^{2}$ of wheat at late sown condition. The experiment was conducted for five consecutive years of 2014-2015 to 20182019. Variation of spikes $/ \mathrm{m}^{2}$ was created by five seed rates $(90,120,150$, 180 and $210 \mathrm{~kg} / \mathrm{ha}$ ). The wheat var. BARI Gom-30 was sown on 15-20 December (late sown condition) in 2014 - 2019. But the optimum sowing time of wheat is 15-30 November in Bangladesh (BARI, 2017). The experiment was laid out in a RCB design with four replications. Unit plot size was $8 \mathrm{~m} 45 \mathrm{~m}$. The crop was fertilized with 100-36-25-20-1.8-1.0 kg/ha of N-P-K-S-Zn-B (BARI, 2011). All the nutrients including two third of $N$ were applied as basal. Rest one third of $\mathrm{N}$ was top dressed at CRI stage. Three irrigations were applied at 20 days after emergence (DAE), 60 DAE and 80 DAE. Crop field was weeded at 25 DAE by spading. The crop was harvested on 27-31 March in 20142019. Data on crop yield and yield components of wheat were recorded. There was no blast infection in the experimental field. Attempt was made to establish functional relationship between grain yield and spikes $/ \mathrm{m}^{2}$ of wheat using the quadratic equation like $\mathrm{Y}=\mathrm{a}+\mathrm{bx}-\mathrm{cx}^{2}$. Optimum seed rate and spikes / $\mathrm{m}^{2}$ could be estimated with the following formula from the developed functional model (Mian et al., 2012).

Optimum seed rate and spikes $/ \mathrm{m}^{2}=-\mathrm{b} / 2 \mathrm{c}$ (where $\mathrm{b}$ and $\mathrm{c}$ are the coefficients).

The experiment was repeated for the consecutive five years to get sufficient data for establishing the functional relationship. Five years' data on spikes $/ \mathrm{m}^{2}$ and grain yield of wheat from 2014-2015 to 2018-2019 were used to develop functional relationship. Some important yield components of wheat were recorded and presented on the basis of year wise and combined analysis (only combined effect). The data was subjected to statistical analysis (year wise and combined) and mean values were compared by $\operatorname{LSD}_{(0.05)}$. 
Yield component and yield

Spikes $/ \mathrm{m}^{2}$ was significantly influenced by seed rate (Table 1). The maximum number of spikes $/ \mathrm{m}^{2}$ was produced of $210 \mathrm{~kg}$ seed /ha (533) followed $180 \mathrm{~kg}$ seed / ha (505) while the lowest in $90 \mathrm{~kg}$ seed /ha (395) in 2014-2015. Similar trend of spikes $/ \mathrm{m}^{2}$ (the highest value ranged 444-573and the lowest value ranged 348-457) was noticed in the subsequent growing season of 20152016 to 2018-2019. The highest pooled value of spikes $/ \mathrm{m}^{2}$ was observed in $210 \mathrm{~kg}$ seed /ha (506) followed by $180 \mathrm{~kg}$ seed /ha (479) while the lowest in $90 \mathrm{~kg}$ seed /ha (398) (Table 1). The results expressed that increasing seed rate increased spikes $/ \mathrm{m}^{2}$ gradually. Similarly, higher spikes $/ \mathrm{m}^{2}$ in higher seed rate (160 $\mathrm{kg} / \mathrm{ha}$ as compared to $120 \mathrm{~kg} / \mathrm{ha}$ ) was also reported by BARI (2018). Seed rate had significant effect on grains / spike (Table 2). The highest grains/ spike was obtained in $90 \mathrm{~kg}$ seed /ha (42) followed by $120 \mathrm{~kg}$ seed /ha (41) but the lowest in $210 \mathrm{~kg}$ seed /ha (34) in 2014-2015 (Table 2). Similar trend of grains / spike (the highest value ranged 38-52 and the lowest value ranged 26-39) was noticed in the following growing seasons of 2015-2016 to 2018-2019. The highest pooled value of grains/ spike was noticed in $90 \mathrm{~kg}$ seed /ha (43) followed by $120 \mathrm{~kg}$ seed /ha (40). On the other hand, the lowest value was found in $210 \mathrm{~kg}$ seed /ha (32) (Table 2). The results reveal that grains/spike was reduced gradually with the increase of seed rate. Higher seed rate possibly exerted inter tiller competition resulting less number of grains/pike. Less number of grains/spike in higher seed rate was also reported by Seleiman et al. (2016) and BARI (2018). The weight of 1000-grain was found the highest in $90 \mathrm{~kg}$ seed /ha $(45 \mathrm{~g})$ followed by $120 \mathrm{~kg}$ seed /ha $(44 \mathrm{~g})$ while the lowest in 210 $\mathrm{kg}$ seed /ha $(39 \mathrm{~g})$ in 2014-2015 (Table 3). Similar trend of 1000-grain weight (the highest value ranged $42-58 \mathrm{~g}$ and the lowest value ranged $32-45 \mathrm{~g}$ ) was observed in the growing season of 2015-2016 to 2018-2019. Pooled value of 1000 -grain weight was recorded the highest in $90 \mathrm{~kg}$ seed /ha $(48 \mathrm{~g})$ followed by $120 \mathrm{~kg}$ seed /ha $(46 \mathrm{~g})$ giving the lowest in $210 \mathrm{~kg}$ seed /ha $(38 \mathrm{~g})$ (Table 3). Higher seed rate possibly exerted inter tiller competition reducing individual grain size and weight as well as lower 1000-grain weight. Reduced 1000-grain weight of wheat at higher seed rate $(160 \mathrm{~kg} / \mathrm{ha})$ was also reported by Seleiman et al. (2016) and BARI (2018). The grain yield of wheat was significantly influenced by seed rate (Table 4). The highest grain yield (3803-3858 kg/ha) was produced in 150-180 kg seed /ha but the lowest (3652 kg/ha) in $90 \mathrm{~kg}$ seed /ha in 2014-2015. On the other hand, the highest grain yield $(5028 \mathrm{~kg} / \mathrm{ha})$ was observed in $180 \mathrm{~kg}$ seed /ha followed by the $210 \mathrm{~kg}$ seed /ha (4839 $\mathrm{kg} / \mathrm{ha}$ ) while the lowest (3652 kg/ha) in $90 \mathrm{~kg}$ seed /ha in 2015-2016 (Table 4). Similar trend of grain yield (the highest grain yield ranged $3738-4376 \mathrm{~kg} / \mathrm{ha}$ and the lowest value ranged $2436-3225 \mathrm{~kg} / \mathrm{ha}$ ) was noticed in the subsequent growing season of 2016-2017 to 2018-2019. Pooled grain yield was obtained the highest in $180 \mathrm{~kg}$ seed /ha (4153 kg/ha) followed by $150 \mathrm{~kg}$ seed /ha (3876 kg/ha) producing the lowest in $90 \mathrm{~kg}$ seed /ha (3418 kg/ha) (Table 4). Grain yield was mainly contributed by spikes $/ \mathrm{m}^{2}$. Similar results have also been described by other investigators (Nemat et al., 2013; Sherwan et al., 2015). Grain yield increased about $6-14 \%$ in $150-180 \mathrm{~kg}$ seed /ha as compared to recommended seed rate $(120 \mathrm{~kg} / \mathrm{ha})$. The results expressed that higher seed rate up to $180 \mathrm{~kg} / \mathrm{ha}$ increased grain yield, afterwards the grain yield declined as the increase of seed rate $(210 \mathrm{~kg} / \mathrm{ha})$. Higher seed rate $(210 \mathrm{~kg} / \mathrm{ha})$ might have exerted more inter tiller competition resulting poorer yield component and grain yield of wheat. Moreover, higher seed rate leads the crop to lodging producing lower grain yield. Higher seed rates $(200 \mathrm{~kg} / \mathrm{ha})$ resulted in higher lodging of wheat was also reported by (Laghari et al., 2011). The results are in agreement with the observation of Seleiman et al. (2016). 
112

Mian et al.

Table 1. Spikes $/ \mathrm{m}^{2}$ (no.) of wheat as influenced by seed rate under late sown condition

\begin{tabular}{c|c|c|c|c|c|c}
\hline $\begin{array}{c}\text { Seed rate } \\
(\mathrm{kg} / \mathrm{ha})\end{array}$ & $\begin{array}{l}2014- \\
2015\end{array}$ & $\begin{array}{l}2015- \\
2016\end{array}$ & $\begin{array}{l}2016- \\
2017\end{array}$ & $\begin{array}{l}2017- \\
2018\end{array}$ & $\begin{array}{l}2018- \\
2019\end{array}$ & Pooled \\
\hline 90 & 395 & 348 & 457 & 383 & 408 & 398 \\
120 & 447 & 362 & 480 & 412 & 428 & 426 \\
150 & 483 & 389 & 493 & 443 & 468 & 455 \\
180 & 505 & 426 & 523 & 464 & 478 & 479 \\
210 & 533 & 444 & 573 & 493 & 485 & 506 \\
\hline LSD (0.05) & 41 & 30 & 34 & 24 & 32 & 33 \\
\hline CV (\%) & 5.66 & 4.87 & 4.33 & 4.69 & 4.91 & 4.89 \\
\hline
\end{tabular}

Table 2. Grains/spike (no.) of wheat as influenced by seed rate under late sown condition

\begin{tabular}{c|c|c|c|c|c|c}
\hline $\begin{array}{c}\text { Seed rate } \\
(\mathrm{kg} / \mathrm{ha})\end{array}$ & $2014-2015$ & $2015-2016$ & $2016-2017$ & $2017-2018$ & $2018-2019$ & Pooled \\
\hline 90 & 42 & 52 & 40 & 41 & 38 & 43 \\
120 & 41 & 48 & 39 & 37 & 36 & 40 \\
150 & 38 & 45 & 38 & 34 & 35 & 38 \\
180 & 37 & 44 & 35 & 30 & 31 & 35 \\
210 & 34 & 39 & 33 & 28 & 26 & 32 \\
\hline $\mathrm{LSD}_{(0.05)}$ & 2.69 & 2.45 & 2.07 & 3.37 & 2.96 & 2.48 \\
\hline $\mathrm{CV}(\%)$ & 4.55 & 3.49 & 3.22 & 4.11 & 5.79 & 4.29 \\
\hline
\end{tabular}

Table 3. Weight of 1000-grain (g) of wheat as influenced by seed rate under late sown condition

\begin{tabular}{c|c|c|c|c|c|c}
\hline $\begin{array}{c}\text { Seed rate } \\
(\mathrm{kg} / \mathrm{ha})\end{array}$ & $2014-2015$ & $2015-2016$ & $2016-2017$ & $2017-2018$ & $2018-2019$ & Pooled \\
\hline 90 & 45 & 58 & 43 & 42 & 50 & 48 \\
120 & 44 & 57 & 41 & 41 & 49 & 46 \\
150 & 43 & 48 & 36 & 38 & 47 & 42 \\
180 & 40 & 46 & 34 & 35 & 46 & 40 \\
210 & 39 & 43 & 32 & 32 & 45 & 38 \\
\hline L SD $(0.05)$ & 2.89 & 4.03 & 3.65 & 2.05 & 2.11 & 2.89 \\
\hline CV (\%) & 4.46 & 5.92 & 4.86 & 2.54 & 2.87 & 4.37 \\
\hline
\end{tabular}

Table 4. Seed yield ( $\mathrm{kg} / \mathrm{ha})$ of wheat as influenced by seed rate under late sown condition

\begin{tabular}{c|c|c|c|c|c|c}
\hline $\begin{array}{c}\text { Seed rate } \\
\text { (kg/ha) }\end{array}$ & $2014-2015$ & $2015-2016$ & $2016-2017$ & $2017-2018$ & $2018-2019$ & Pooled \\
\hline 90 & 3652 & 4520 & 3225 & 3187 & 2436 & 3418 \\
120 & 3781 & 4592 & 3743 & 3405 & 2804 & 3651 \\
150 & 3858 & 4633 & 4061 & 3532 & 3295 & 3876 \\
180 & 3803 & 5028 & 4376 & 3738 & 3822 & 4153 \\
210 & 3586 & 4839 & 4065 & 3584 & 2464 & 3708 \\
\hline LSD $(05)$ & 287 & 378 & 373 & 318 & 313 & 328 \\
\hline CV (\%) & 4.98 & 5.21 & 6.22 & 5.93 & 5.59 & 5.66 \\
\hline
\end{tabular}

\section{Functional relationship}


Functional relationship between seed rate and spikes $/ \mathrm{m}^{2}$ indicates that the effect of seed rate on spikes $/ \mathrm{m}^{2}$ of wheat can be explained $72 \%$ by functional model of $\mathrm{Y}=2.8613 \mathrm{X} \quad\left(\mathrm{R}^{2}=0.72\right) \quad$ (Table 5 and Fig.1). The coefficient value of 2.8613 indicates that the number of spikes $/ \mathrm{m}^{2}$ would be increased @ 2.8613 with the increase of $1 \mathrm{~kg} / \mathrm{ha}$ of seed rate. Spikes $/ \mathrm{m}^{2}$ showed significant positive correlation with the seed rate $(r=0.79$ at $p=0.05)$. Functional relationship between seed rate and grain yield of wheat shows that the effect of seed rate on grain yield can be explained $87 \%$ by functional model of $\mathrm{Y}=485.91+43.17 \mathrm{X}-0.133 \mathrm{X}^{2}$ $\left(\mathrm{R}^{2}=0.87\right)$ (Table 5 and Fig.2). Number of spikes $/ \mathrm{m}^{2}$ had a great impact on the grain yield of wheat as described by Moucheshi et al. (2013). The optimum seed rate was estimated at $162.29 \mathrm{~kg} / \mathrm{ha}$ by the functional model of $\mathrm{Y}=485.91+43.17 \mathrm{X}-0.133 \mathrm{X}^{2} \quad\left(\mathrm{R}^{2}=0.87\right)$. Then the grain yield would be 3989 $\mathrm{kg} / \mathrm{ha}$ at the estimated seed rate of $162.29 \mathrm{~kg} / \mathrm{ha}$. Again, functional relationship between spikes $/ \mathrm{m}^{2}$ and grain yield of wheat indicates that the effect of spikes $/ \mathrm{m}^{2}$ on grain yield can be explained $83 \%$ by functional model of $\mathrm{Y}=-2837+32.98 \mathrm{X}-$ $0.039 \mathrm{X}^{2}\left(\mathrm{R}^{2}=0.83\right)$ (Table 5 and Fig. 3). The estimated optimum spikes $/ \mathrm{m}^{2}$ was found 423 by the functional model of $Y=-2837+32.98 \mathrm{X}-0.039 \mathrm{X}^{2}\left(\mathrm{R}^{2}=0.83\right)$.

Table 5. Relationship between different parameters of wheat as influenced by seed rate

\begin{tabular}{|l|l|l|c|}
\hline $\begin{array}{l}\text { Fig. } \\
\text { no. }\end{array}$ & \multicolumn{1}{|c|}{ Variable } & \multicolumn{1}{|c|}{ Functional relationship } & \multicolumn{1}{c|}{$\mathrm{R}^{2}$} \\
\hline 1. & Seed rate and spikes $/ \mathrm{m}^{2}$ & $\mathrm{Y}=2.8613 \mathrm{X}$ & $\mathrm{R}^{2}=0.72$ \\
\hline 2. & Seed rate and grain yield & $\begin{array}{l}\mathrm{Y}=485.91+43.17 \mathrm{X}- \\
0.133 \mathrm{X}^{2}\end{array}$ & $\mathrm{R}^{2}=0.87$ \\
\hline 3. & Spike $/ \mathrm{m}^{2}$ and grain yield & $\begin{array}{l}\mathrm{Y}=-2837+32.98 \mathrm{X}- \\
0.039 \mathrm{X}^{2}\end{array}$ & $\mathrm{R}^{2}=0.83$ \\
\hline 4. & $\begin{array}{l}\text { Observed and predicted grain } \\
\text { yield }\end{array}$ & $\mathrm{Y}=1.0006 \mathrm{X}$ & $\mathrm{R}^{2}=0.94$ \\
\hline- & Seed rate and spikes $/ \mathrm{m}^{2}$ & correlation coefficient & $\begin{array}{c}\mathrm{r}=0.79 \text { at } \\
\mathrm{p}=0.05\end{array}$ \\
\hline- & $\begin{array}{l}\mathrm{r}=0.97 \text { at } \\
\mathrm{p}<0.01\end{array}$ \\
\hline
\end{tabular}

Then the grain yield would be $4135 \mathrm{~kg} / \mathrm{ha}$ at the estimated spikes $/ \mathrm{m}^{2}$ of 423 giving $13 \%$ higher grain yield as compared to recommended seed rate (120 $\mathrm{kg} / \mathrm{ha}$ ) of wheat. Kadum et al. (2019) reported that $481-492 \mathrm{spikes} / \mathrm{m}^{2}$ gave the highest grain yield (6.46-6.62 t/ha) of wheat. Sokoto et al. (2012) also found that spikes $/ \mathrm{m}^{2}$ had significant positive correlation with grain yield of wheat. Relationship between observed grain yield and predicted grain yield (when relationship between spikes $/ \mathrm{m}^{2}$ and grain yield by the functional model of $\mathrm{Y}=-$ $\left.2837+32.98 \mathrm{X}-0.039 \mathrm{X}^{2}, \quad \mathrm{R}^{2}=0.83\right)$ showed a good consistency ( $\mathrm{Y}=1.0006 \mathrm{X}$, $\mathrm{R}^{2}=0.94$ and $\mathrm{r}=0.97$ at $\mathrm{p}<0.01$ ) (Table 5 and Fig. 4). 
Mian et al.

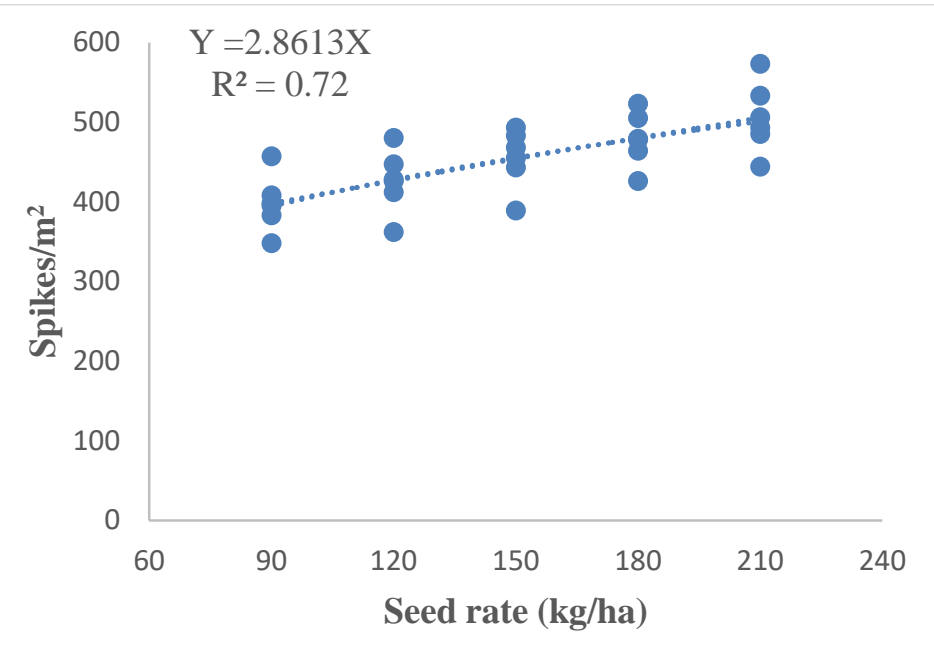

Fig. 1. Functional relationship between seed rate and spikes $/ \mathrm{m}^{2}$ of wheat

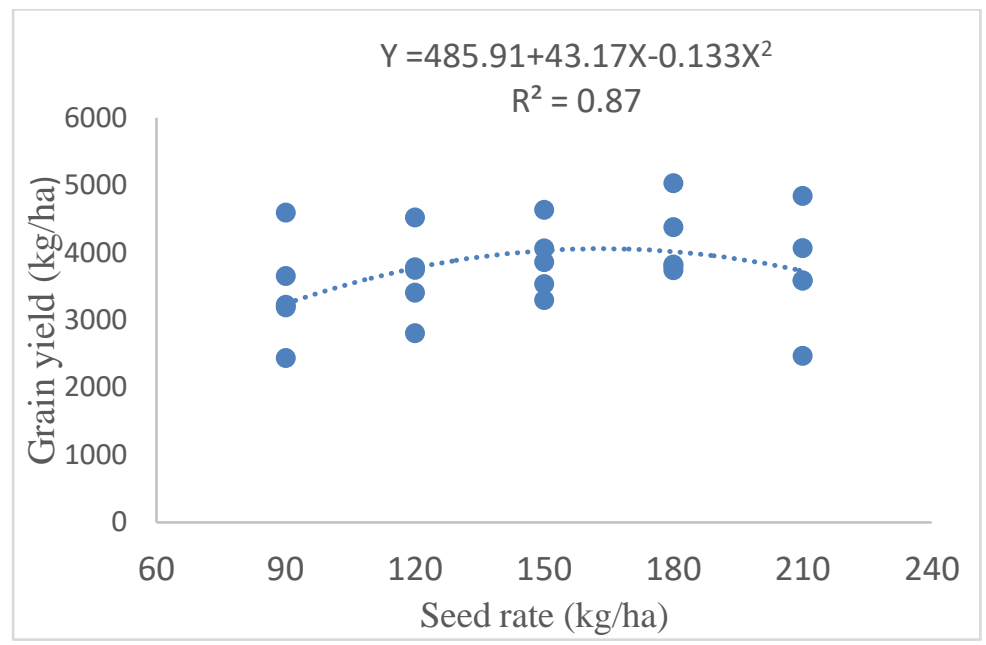

Fig. 2. Functional relationship between seed rate and grain yield of wheat 


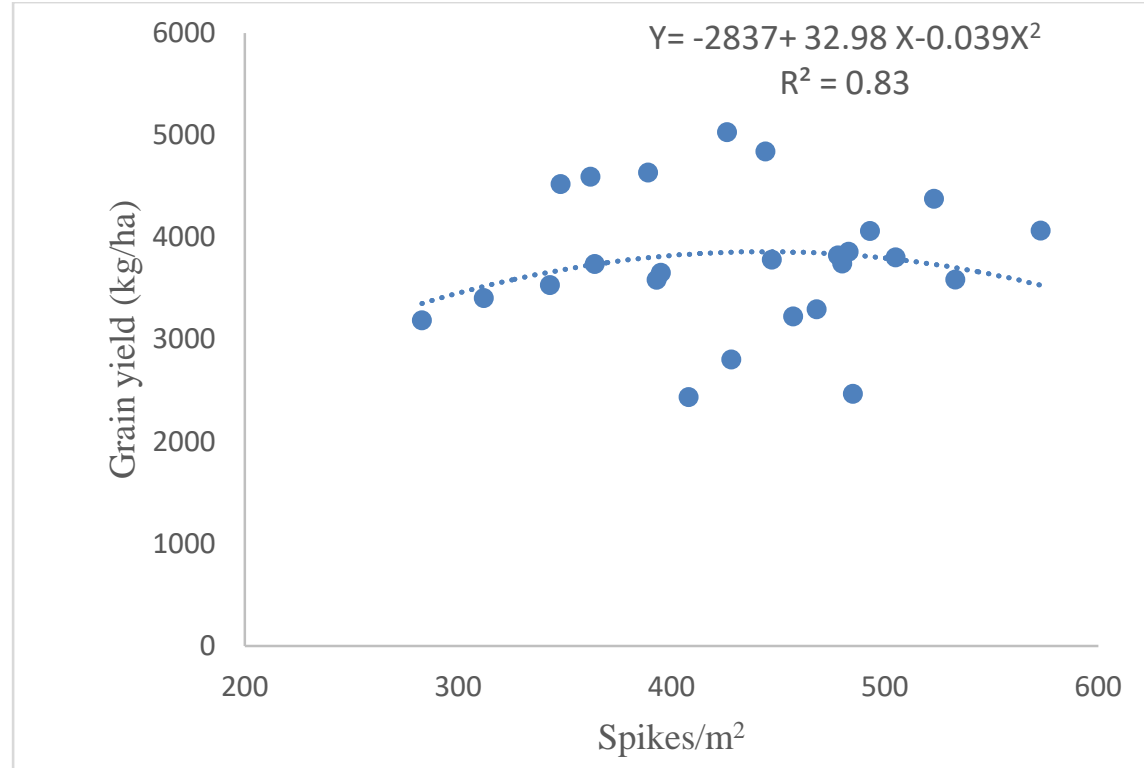

Fig. 3. Functional relationship between spike $/ \mathrm{m}^{2}$ and grain yield of wheat

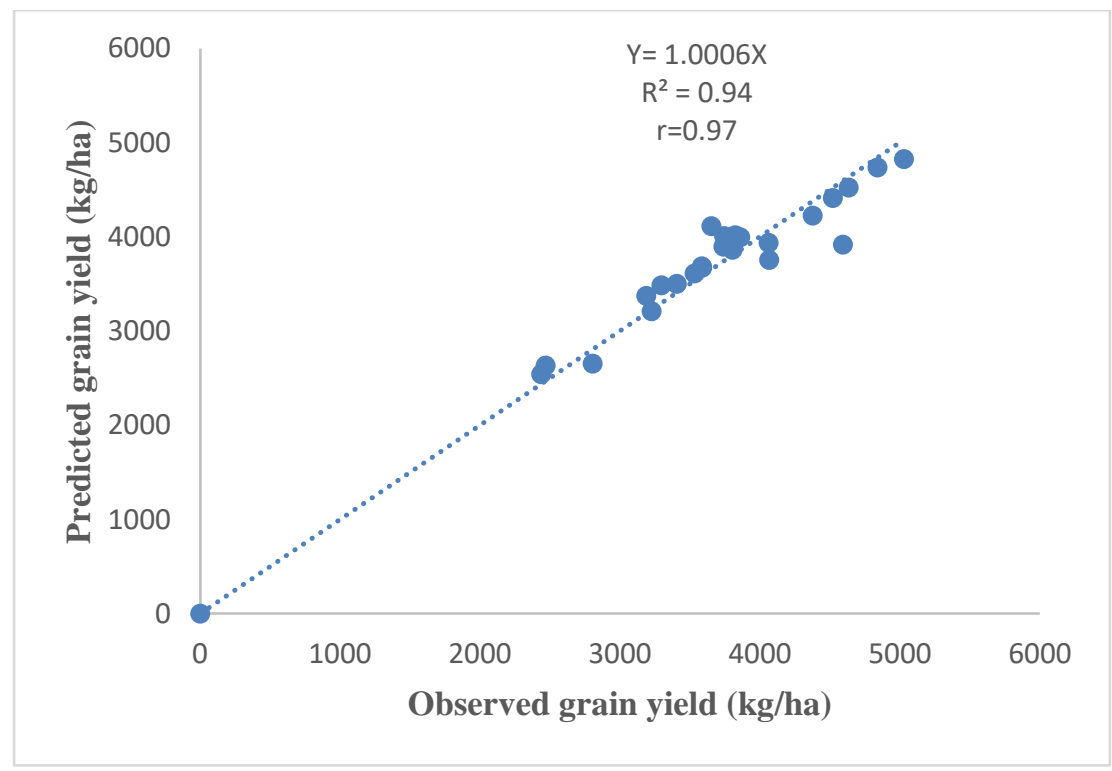

Fig. 4. Relationship between observed and predicted grain yield of wheat (Functional model of spike $/ \mathrm{m}^{2}$ and grain yield of wheat; $\mathrm{Y}=-2837+$ $\left.32.98 \mathrm{X}-0.039 \mathrm{X}^{2}, \mathrm{R}^{2}=0.83\right)$ 
Mian et al.

From the structural treatment, the highest grain yield (pooled of 3876-4153 $\mathrm{kg} / \mathrm{ha}$ ranged $3295-5028 \mathrm{~kg} / \mathrm{ha}$ ) of wheat was produced with $150-180 \mathrm{~kg}$ seed / ha. The estimated optimum seed rate was $162.29 \mathrm{~kg} / \mathrm{ha}$ when the estimated grain yield was $3989 \mathrm{~kg} / \mathrm{ha}$ of wheat at late sown condition through the developed function. Furthermore, the estimated optimum spikes / $\mathrm{m}^{2}$ was 423 with the estimated grain yield of $4135 \mathrm{~kg} / \mathrm{ha}$ of wheat at late sown condition through the developed function. Then the grain yield would be increased about $13 \%$ as compared to recommended seed rate $(120 \mathrm{~kg} / \mathrm{ha})$ of wheat. About 162 $\mathrm{kg} / \mathrm{ha}$ of seed rate may be recommended for late sown wheat.

\section{References}

AIS (Argil.Information Service). 2018. Krishi Diary (In Bangla). Department of Argil. Extension. Khamarbari, Dhaka1215. pp.14-119.

BARC (Bangladesh Agril. Res. Council). 2013. Hand Book of Agricultural Technology. BARC. Farmgate, Dhaka 1215. pp.21-22.

BARI (Bangladesh Agril. Res. Inst.) 2011. Krishi Projukti Hatboi (Hand book of Agro-technology). BARI. Gazipur 1701.pp.1-18.

BARI (Bangladesh Agril. Res. Inst.) 2017. Krishi Projukti Hatboi (Hand book of Agro-technology). BARI. Gazipur1701. pp. 1-7.

BARI (Bangladesh Agril. Res. Inst.) 2018. Adjustment of seed rate for $\mathrm{Zn}$ enriched wheat variety BARI Gom-33. In: BARI Annual Report (2017-18). BARI. Gazipur 1701. pp. 15-16.

Begum, A.A. and M.A.K. Mian. 2019. Estimation of temperature co-efficient of wheat for adjusting proper sowing time. In: Annual Research Report (2018-19). Agron. Div. BARI. pp..185-194.

Bolton, F.E. 2018. Field and other agronomic characters of winter wheat cultivars as affected by five seeding rates and three different environmental conditions. A Thesis. Master of Science. Agronomic Crop Science. Oregon state University. USA. (https://ir.library.oregonstate.edu/downloads/ft848t13w; visited on 17 June 2018). pp.31-36.

Kadum, M.N., N.A. Mutlag, and A.J. Al-Khazal. 2019. Evaluation of the performance of bread wheat genotypes in central region of Iraq by using selection technique. Res. J. Chem. Environ. 23: 17-22.

Laghari, G. M., F.C. Oad, and S. Tunio. 2011. Growth and yield attributes of wheat at different seed rates. Sarhad J. Agric. 27(2): 177-183.

Mian, M.A.K. 2008. Performance of maize oriented cropping patterns under different nutrient management. Ph.D. Dissertation. Agronomy Div. Bangladesh Agricultural University, Mymensingh. pp.54-59.

Mian, M.A.K., K.U. Ahammad, M.N. Islam, N.A. Sultana and M.S. Alam. 2012. Assessing simple functional yield model for mustard-Boro rice- T.aman rice cropping pattern under nutrient management. Bull Inst. Trop. Agr. Kyushu Univ. 35: 1-9.

Mian, M.A.K., M.R. Islam, J. Hossain and and M.A. Aziz. 2016. Grain growth of wheat under prevailing air temperature. Bangladesh Agron. J. 19(2): 79-85.

Mian, M.A.K and A.A. Begum. 2018. Crop Productivity in Beel Area of Bangladesh. Project Completion Report. NATP-2, BARC. Farmgate, Dhaka-1215.pp.12-22.

Moucheshi, A.S., M. Pessarakli and B. Heidari. 2013. Comparing relationship among yield and its related traits in mycorrhizal and nonmicorrhizal 
inoculated wheat cultivars under different water regimes using multivariate statistics. Inter J. Agron. 10: 81-95.

Nemat, A., Noureldin and H.S. Saudy. 2013. Grain yield response index of bread wheat cultivars as influenced by nitrogen levels. Ann. Agril. Sci. 58(2): 147-152.

Njuguna, M.N., M. Munene and H.G. Mwangi 2010. Effect of seeding rate and nitrogen fertilizer on wheat grain yield in marginal areas of eastern Kenya. J. Anim. Plant Sci. 7(2): 834-840.

Shankarrao, B. S., S. Mukherjee, A.K. Pal and D.K. De. 2010. Estimation of variability for yield parameters in Bread Wheat (Triticum aestivum L.) grown in Gangetic West Bengal. Electron. J. Plant Breed, 1(4): 764-768.

Sherwan, I.T., H.A. Shang and K.S. Ahmad. 2015. Response of grain yield and its component to organic matter and removal of some photosynthetic organs of durum wheat in two years of Sulaimani-Iraq region. Intl. $\mathrm{J}$. Plant Anim. Environ. Sci. 5(4): 134-140.

Shewry, P.R. and J.H. Sandry. 2015. The contribution of wheat to human diet and health. Food Energy Secur. 4(3): 178-202.

Seleiman, M.F., M.E. Ibrahim, S.M. Abdel-Al and G.A. Zahran. 2016. Effect of seed rate on productivity technological and rheological characteristics of bread wheat (Triticum aestivum). Intl. J. Current Res. 4: 75-81.

Sokoto, M.B., I.U. Abubakar and A.U. Dikko. 2012. Correlation analysis of some growth, yield, yield components and grain quality of wheat (Triticum aestivum L.). Nig. J. Basic Appl. Sci. 20(4): 349-356. 